\title{
THE TRUE MEANING OF FORCE
}

\author{
Mary Ellen O'Connell*
}

Tom Ruys's article ${ }^{1}$ in the latest issue of the American Journal of International Law is an erudite study of the prohibition on the use of force in UN Charter Article 2(4). Ruys makes many points with which I wholeheartedly agree. In note 241 , he says that the case for cross-border drone attacks by the United States "verges on stretching criteria for necessity, proportionality, and armed attack to the point of absurdity ...." He is also right to reject emerging claims that the defense of necessity provides a basis for the lawful resort to force. Indeed, there is much that is truly excellent about the article-just not, unfortunately, its central thesis.

At the outset, Ruys indicates his thesis is that Article 2(4) prohibits all force in international relations no matter how minor: a navy vessel firing a single shot across the bow of a foreign ship is covered by Article 2(4) because "excluding small-scale or 'targeted' forcible acts from the scope of Article 2(4) is conceptually confused, inconsistent with customary practice, and undesirable as a matter of policy." ${ }^{2}$ Ruys is opposed to the position taken by Olivier Corten, Robert Kolb, the Independent International Mission on the Conflict in Georgia, this author, and many others that Article 2(4) excludes minor uses of armed force from its scope. By the end of the article, however, Ruys, too, concludes "the gravity or intensity" of forcible conduct is an essential consideration in forming a lawful response. ${ }^{3}$

It seems that Ruys may not be as concerned about accurately interpreting Article 2(4) as he is in advocating for an expansion of the right to use armed force. In the middle of the article Ruys says he "believes" the world should "adopt a more flexible, functional reading of the right of self-defense." 4 He urges that any use of force prohibited by Article 2(4) should permit a state to respond using a "form of self-defense." 5 B advocating for even minor uses of force to be included in Article 2(4), he expands the instances in which he would allow states to resort to armed force.

A prime reason for his interest in expanding the right to resort to armed force is something he calls the "gap' conundrum." Ruys is concerned that if a state is the victim of an unlawful but minor use of force it does not currently have the right to respond with force prohibited by Article 2(4). This is not in fact a "gap." The victim state might have the right to respond to a minor use of armed force with a minor use of armed force under the law of countermeasures. The only possible "gap" is where a state wishes to use more than minor armed force in situations that do not satisfy the conditions for resort to force in self-defense under

\footnotetext{
* Robert and Marion Short Professor of Law and Research Professor of International Dispute Resolution-Kroc Institute, University of Notre Dame. Originally published online 4 Aug. 2014.

${ }^{1}$ Tom Ruys, The Meaning of "Force" and the Boundaries of the Jus Ad Bellum: Are "Minimal Uses of Force Excluded From UN Charter Article 2(4)?, 108 AJIL 159 (2014).

${ }^{2} \underline{I d}$. at 159 .

${ }^{3} \underline{I d}$. at 207.

${ }^{4} \underline{I d}$. at 181 .

${ }^{5} \underline{I d}$.

${ }^{6} \underline{I d}$.
} 
Article 51 and where the state has not received authorization to use such force from the Security Council. Article 51 says states may resort to self-defense "if an armed attack occurs." The International Court of Justice has found in interpreting Article 51 that the armed attack must be significant, something more than mere border incursions.

Ruys does not solve this alleged "gap" by expanding Article 2(4) to include minor uses of force; he increases it. If Article 2(4) includes minor uses of force, even the victim of a minor use of force violates Article 2(4) by responding in kind. Having increased the gap, Ruys then proposes expanding the right to resort to some "sort of self-defense" in response to force he argues is part of Article 2(4). Again, the scope of Article 2(4) does not seem to be Ruys's real concern. His concern and the focus of the article is his interest in expanding the right to resort to force in self-defense, which was also the point of his book on armed attack.

By focusing on the scope of Article 2(4), however, Ruys is able to develop examples that he presents as demonstrating a confused, gap-ridden, and internally contradictory regime on the use of force. His proposal for expanding self-defense appears as a much-needed reform. Yet, the regime on the use of force needs no such reform. Like any system of rules, law on the use of force can be improved. The area in greatest need of improvement is with compliance, not greater flexibility and expanded rights to resort to force.

Ruys's case against the regime of force does not hold up. There is no true "gap conundrum." International law has an uninterrupted set of rules regulating forceful conduct that ranges from the rules on retorsionsnegative but lawful conduct such as withdrawing ambassadors - to the jus cogens prohibition of aggression. Considered from the perspective of responses to unlawful force, there are, again, no true gaps: States have basically no restrictions on the employment of retorsions; they may respond to any unlawful use of force with commensurate countermeasures that do not violate Article 2(4). States may respond if a significant armed attack occurs with a use of force in self-defense. Self-defense means the right to use force on the territory of a state responsible for the armed attack. The Security Council may authorize the use of force in response to threats to the peace, breaches of the peace, and acts of aggression.

Even if the system did have an important gap, the UN Charter is not going to be amended explicitly or implicitly any time soon to accommodate Ruys's proposal. This is all the more true of Article 2(4) because it includes the peremptory norm prohibiting aggression, meaning it is not subject to change by treaty amendment or by a change in state practice. Article 2(4) is also a treaty rule, and as such it, too, is not subject to change in the way rules of customary international law may change with general state practice reflecting opinio juris.

State practice is nevertheless relevant to interpreting Article 2(4). Ruys presents a good many examples to support his case but not the most important one, which opposes it. He does not mention the very significant practice represented by the 2005 UN World Summit in New York in which the entire UN membership determined that the Charter rules on the use of force were satisfactory. The members committed to strictly comply with them. This state practice closes the case for interpreting the Charter as permitting another "sort of self-defense" to respond to violations of Article 2(4) other than an Article 51-type armed attack.

Just a few more words on the subject of the meaning of force in Article 2(4). Ruys concedes that Olivier Corten and I have provided extensive state practice reflecting that minimal uses of force fall below Article 2(4)'s scope. He is not saying the case for the de minimis force exception is weak. He just believes the case against excluding minor armed force is stronger. This might suggest an ordinary subjective difference of opinion, but, in fact, the weight of the evidence is heavily against Ruys's position, providing more evidence that his real concern is to expand self-defense.

The starting place against the Ruys position is the Charter's negotiating history, which makes clear that Article 2(4) was intended to prohibit force broadly but not to regulate all conceivable forceful action. Ruys 
admits the drafters excluded economic force. The exclusion was not to concede that economic force was unregulated in international law. Economic force is regulated under the rules of non-intervention, international economic law, property rights, and other principles. Armed force is clearly included in Article 2(4), but de minimis exceptions are an inherent part of many legal rules, and the long practice under the Charter since 1945 demonstrates that Article 2(4) does not cover minor force.

The de minimis exception to the Article 2(4) prohibition is also a matter of practicality and common sense. The regime of countermeasures is adequate to regulate minor uses of force that states engage in all of the time. Just consider the cases of navies pursuing fishing vessels, soldiers wandering across borders, accidental air incursions, and unapproved cross-border law enforcement operations. States protest when the victims of such force and may even take counter-countermeasures but only rarely do they invoke Article 2(4). Even when they do, some instances are plainly meant rhetorically and not as a serious legal claim.

No doubt a few cases of low-level force have been treated as Article 2(4) violations, but most of Ruys's examples are ambiguous or unhelpful to his argument. Many consist of a state referring to "force" or "aggression" and not Article 2(4) specifically. References to "force" can be to the type of force below the Article 2(4) threshold. Charges of "aggression" in cases of minor uses of force are often hyperbole and not intended to invoke Article 2(4), let alone the actual prohibition of aggression.

In reviewing just one of Ruys's many examples, we see the type of problems typical of his analysis of state practice. In 1968, North Korea captured the USS Pueblo. The United States called the capture "aggressive military action" in violation of the Charter. ${ }^{7}$ Ruys quotes no express reference to Article 2(4). There are other provisions of the Charter that North Korea plainly violated. The reference to the Charter could have been to the failure to use peaceful measures of dispute settlement. The United States could also have been charging a violation of the Charter mandate to respect human rights.

The Pueblo example also leads to Ruys discussion of rescue and capture. The crew of Pueblo certainly had the right to defend their lives and liberty with what Dinstein calls "on-the-spot reaction." Ruys tries to use such defense to bolster his case for a new type of sovereign state self-defense. "On-the-spot reaction" is akin to personal self-defense, which is found in all national criminal codes. It is part and parcel of the human right to life. It is not the self-defense of Article 51 or that which Ruys is proposing. Personal self-defense is already permitted in the law and does not require adopting Ruys's proposal to be lawful.

Current law also permitted the United States to attempt to rescue the crew of the Pueblo. Indeed, it is the regime of countermeasures that permits rescue attempts and attempts to apprehend criminal suspects such as Osama bin Laden or Abu Khattala. Rescue and apprehension of international criminal suspects where the state carrying out the operation lacks a territorial state's consent may still be lawful under the law of countermeasures. Countermeasures permit entering onto state territory without consent where the territorial state has failed in its international law obligations, such as the obligation of due diligence to detain, try, or extradite certain criminal suspects. The apprehension must follow law enforcement rules, which restrict the use of lethal force, ensuring no breach of Article 2(4).

The United States complied with these rules in the June 16, 2014, apprehension of Abu Khattala in Benghazi, Libya. The breakdown of authority in Libya was such that under the law of countermeasures, no consent was needed given that Libya was on notice of its duty to apprehend the suspect but failed to do so. The military personnel involved in the Khattala operation followed police-type law enforcement rules. The force involved was below the Article 2(4) threshold. Under the Ruys interpretation the operation breached Article 2(4) and was unlawful. (He mentions a 2013 operation in Libya that he believes was lawful because

${ }^{7} \underline{I d}$. at 185 . 
authorities gave consent. ${ }^{8}$ The United States had no consent in the Abu Khattala case.) Ruys might reply that under his proposal, the United States could justify a future operation of this type as a "sort of self-defense." As explained above, however, his proposal is not the law and is most unlikely to become the law.

In a blog post on the Abu Khattala case, Martin Lederman, a former Obama administration lawyer tasked with advising on drone attacks, wrote ${ }^{9}$ that the Khattala operation was justified on the basis of Article 51 selfdefense. He relied for that view on a letter from U.S. Ambassador Samantha Power to the United Nations. Lederman's misunderstanding is understandable, perhaps, given that he is no specialist in the international law on the use of force. The Ambassador's letter is more of a mystery.]

Another example of Ruys's evidence from the post-9/11 world concerns state practice related to "targeted attacks" or "targeted killing." Ruys says there is evidence that states see "targeted" attacks or killing as a violation of Article 2(4). "Targeted" is not, however, a term of art respecting a type of force. It could refer to minor or a major force. States employ the term in different ways. Assassinations by poisoning, knifing, or shooting an individual have been called "targeted" killings. The United States calls launching multiple tankkilling Hellfire missiles from a drone at a group of people "targeted killing." One case implicates human rights law and the non-intervention principle. The other case implicates human rights law, the nonintervention principle, and Article 2(4). The quantity of force matters.

Ruys does perceive the very steep downside of including minor uses within the prohibited force of Article 2(4), especially when paired with his proposal to allow more force in self-defense. He, therefore, adds to his argument the additional requirement that the responding state consider the gravity of the force and the "intent" behind the use of force. ${ }^{10}$ Political scientists use intent to help them determine what counts as an "armed conflict." In international law, however, we judge on the basis of observable facts, not what we can perceive is in the head of a national leader or a thug. If the facts on the ground indicate organized armed fighting of some intensity, under international law it is an armed conflict. ${ }^{11}$ As Brownlie pointed out decades ago, intent, fault, and other mental states do not lend themselves to these international law questions. More importantly, Ruys can point to no authority requiring states to consider intent. He uses examples that rather show state restraint in the face of minor uses of force.

And his consideration of gravity brings us back to the starting point that Article 2(4) excludes minimal uses of force.

"Force" is a term in the law, like so many terms, that does not have a strict meaning. Interpreting such a term in a rule like Article 2(4) and applying it to a concrete situation requires judgment. To guide that judgment, international law has certain overarching, some would say constitutional, principles. With respect to the use of force, those principles are found in the object and purposes of the UN Charter. The United Nations was established to save succeeding generations from the scourge of war and to promote human rights, prosperity, and the peaceful settlement of disputes. In a close case of judgment as to whether a forcible countermeasure might involve too much force and, therefore, violate Article 2(4), a national leader should avoid risking the violation by reformulating the countermeasure.

As a final note, I wish to appeal to the new co-editors in chief of the American Journal of International Law. Ruys's is the fourth major article in four years in the pages of the Journal concerned with expanding the right to resort to armed force. The world could use a major article in defense of peace, for a change.

${ }^{8} \underline{I d}$. at 169.

9 Marty Lederman, The Legal Basis for the Abu Khattalah Capture, JusT SECURITY (June 19, 2014).

10 See Ruys, supra note 1 , at 171.

11 International Law Association: Use of Force Committee, Final Report on the Meaning of Armed Conflict in INTERNATIONAL LAW (2010). 